\title{
Proceeding
}

Supplementary Issue: Rio 2016 Olympic Games Third Anniversary Special Edition. Olympic Studies Forum, 2-3 September

2019. Federal University of Sergipe, Aracaju, Brazil

\section{Brazilian Paralympic sport initiation: The road from Rio to Los Angeles}

\author{
VINÍCIUS DENARDIN CARDOSO1,2,3,4 , MARCELO DE CASTRO HAIACHI 2,3,4, AUGUSTO CÉSAR \\ ALVES DOS SANTOS 2,3 , SARAH CRISTINA MONTES CANUTO ${ }^{2,3}$, LUCAS PORTILHO NICOLETTI ${ }^{1}$ \\ ${ }^{1}$ State University of Roraima, Brazil \\ ${ }^{2}$ Federal University of Sergipe, Brazil \\ ${ }^{3}$ Research Group on Olympic and Paralympic Studies (GPEOP), Brazil \\ ${ }^{4}$ Brazilian Paralympic Academy, Brazil
}

\begin{abstract}
The Paralympic Games are the largest high-performance sport competition for athletes with disabilities (motor, visual and intellectual). Brazil is evolving in the medal table with each edition of the Games, and the country's growth and sporting improvement since the Sydney 2000 Paralympic Games. After Rio 2016 Paralympic Games grow up the necessity of renewal of Brazilian Paralympic talent. This study aims to bring reflections on the actions developed in Brazil that can contribute and improve the formation of new generations of Brazilian Paralympic athletes. This study are bibliographic search was conducted in national and international databases such as: SCIELO, Science Direct, Google Scholar, as well as in the Thesis Bank of the Coordination of Improvement of Higher Education Personnel (CAPES) and also in institutional documents and institutional websites. Paralympic School Games is the most recognized initiative of paralympic sports initiation and have already been the showcase of some of the most talented brazilian athletes and can be considered the main way to reveal new athletes with disabilities in Brazil. Also, University Paralympic Games, School Camping and Paralympic Training Center increase this process in Brazil. Thus, the Paralympic Games of 2024 and 2028, bring good perspectives for the brazilian paralympic sport, besides the possibility of proving the capacity of renewal of paralympic talents, can consolidate the continuity of the country as power in the world paralympic scenario. Keywords: Paralympic sport; Paralympic athlete; Paralympic initiation; Paralympic Games.
\end{abstract}

Cite this article as:

Cardoso, V.D., Haiachi, M.C., Dos Santos, C.A., Canuto, S.C.M., \& Nicoletti, L.P. (2020). Brazilian Paralympic sport initiation: The road from Rio to Los Angeles. Journal of Human Sport and Exercise, 15(1proc), S111-S117. doi:https://doi.org/10.14198/jhse.2020.15.Proc1.11

Corresponding author. Street: 7 de Setembro, 231. Neighborhood: Canarinho. 69306-530 City: Boa Vista, RR - Brazil.

E-mail: vinicardoso@yahoo.com.br

Supplementary Issue: Rio 2016 Olympic Games Third Anniversary Special Edition. Olympic Studies Forum, 2-3 September 2019. Federal University of Sergipe, Aracaju, Brazil.

JOURNAL OF HUMAN SPORT \& EXERCISE ISSN 1988-5202

(c) Faculty of Education. University of Alicante

doi:10.14198/jhse.2020.15.Proc1.11

VOLUME 15 | Proc1 | 2020 | S111 


\section{INTRODUCTION}

The Paralympic Games are the largest high-performance sport competition for athletes with disabilities (motor, visual and intellectual). The growth of the games is noticeable with each new edition, not only in the number of participants, the level of performance of the athletes, the number of records exceeded but also in the prominence that the sponsors and the world media have given to the games.

The Sydney 2000 Paralympic Games can be considered a milestone in the country's evolution on the international stage. The 24th place in the overall medal table of this edition, although far from the first place, gave high visibility to the Brazilian Paralympic sport, thus allowing a recognition of the achievements of Paralympic athletes, by government agencies and sponsors, as well as by a part of the Brazilian population (Costa; Santos, 2002).

In 2004 in Athens, Greece, Brazil reaches 14th position. Already, 2008 in Beijing, China, was reached the 9th position. In 2012 in London, England, Brazil reached the 7th place in the medal ranking, the best place in its history, and in Rio 2016 Games we reached the 8th place. This shows that Brazil is evolving in the medal table with each edition of the Games, and the country's growth and sporting improvement since the Sydney 2000 Paralympic Games is remarkable.

On the eve of the Tokyo 2020 Paralympic Games, the Brazilian Paralympic Sport is experiencing a moment of sports renewal. The results of the different modalities in recent national and international competitions like 5th place finish at the Rio 2016 Paralympic Games highlighted a premise: the importance of the process of renewal of the Brazilian Paralympic generation.

This form, the process of sport initiation of Paralympic athletes is important for the discovery of new generations of athletes in the country and the possibility of keeping the country among the top 10 powers of the world Paralympic sport in the upcoming Games.

The objective of this study is to bring reflections on the actions developed in Brazil that can contribute and improve the formation of new generations of Brazilian Paralympic athletes who can represent the country at the 2024 Paralympic Games in Paris and 2028 in Los Angeles.

\section{MATERIALS AND METHODS}

This study has a qualitative approach and exploratory and descriptive procedures (Gaya, 2008). Through theoretical reflection with the literature, the text seeks to bring discussions and reflections on the actions of Paralympic sports initiation in Brazil.

To substantiate the study, a bibliographic search was conducted in national and international databases such as: SCIELO, Science Direct, Google Scholar, as well as in the Thesis Bank of the Coordination of Improvement of Higher Education Personnel (CAPES) and also in institutional documents and institutional websites.

\section{RESULTS AND DISCUSSION}

In Brazil, the most recognized initiative of Paralympic sports initiation comes in 2006, the Paralympic School Games. Created with the aim of fostering the emergence of new Paralympic talent, promoting integration, 
socio-cultural exchange and increasing the participation of students with disabilities in sporting activities, it is the largest national Paralympic competition for young people with disabilities in public and private schools in the country (Cardoso, 2016; Silva, 2017; Bataglion; Mazo, 2019).

Since 2006, the Paralympics School Games have already been the showcase of some of the most talented Brazilian athletes. Petrúcio Ferreira, world and Paralympic athletics champion; Alan Fonteles, World and Paralympic Athletics Champion; Lorena Spoladore and Veronica Hipólito, World Athletics Champions, and Leomon Moreno, World Goalball Champion, are some of the names that have gone through the largest student competition in the country (BRASIL, 2016).

Currently Paralympic School Games can be considered the main way to reveal new athletes with disabilities in Brazil, between 2006 and 2018, already had over 10,000 athletes with disabilities from all the federative units of the country and also from other countries (United Kingdom) (CPB, 2015).And is considered the biggest competition for young students with disabilities in the world (CPB, 2019a).

It is in this competition that new generations are emerging in the country. Cardoso (2016), in a study with 20 Brazilian Paralympic medal athletes, portrays the importance given to this competition by the investigated athletes.

Also, Andrew Parsons, former president of the Brazilian Paralympic Committee (CPB) and current president of the International Paralympic Committee - IPC, also highlights the importance of this competition: "the gateway to the sport. In addition, we have examples of sportsmen who started their careers in a School edition and today are among the best athletes in the world." (BRASIL, 2014).

A major concern of the CPB was the departure of athletes from the Paralympics School Games and their continuity in the high-performance sport, as many students with disabilities closed the Basic Education cycle and had no more school competitions to participate.

In 2016, after the Rio 2016 Paralympic Games, a Paralympic competition emerges as a milestone to promote the renewal of the Paralympic athletes and continuity of the academic walk: The University Paralympics Games.

The University Paralympics Games were already part of CPB's strategic planning for the 2010-2016 period, and its first edition took place in November 2016, as a result of CPB's partnership with the Ministry of Sport, with the support of the São Paulo State Government and the Federal Council of Physical Education (CPB, 2010).

Calegari et al. (2017) highlights that the increasing access of athletes with disabilities to higher education motivated the CPB to propose the creation of the University Paralympics. In addition, Reis (2014) points out that the Agnelo Piva Law already requires a 10\% investment in school sports and $5 \%$ in university sports. This was one of the ways to ensure that the value invested in a particular destination was targeted and that they were not neglected and / or forgotten.

In its first edition, 154 athletes from 18 federation units participated. By 2019, 382 athletes from 22 federation units participated in eight sports: athletics, Paralympic boccia, $3 \times 3$ basketball, judo, swimming, Para badminton, table tennis, wheelchair tennis, an increase of $148 \%$ over the first edition. 
Each year it is possible to see a substantial growth in the number of participants, which allows a growth of modalities to be disputed in games, this growth also demonstrates an increase in the access of people with disabilities to higher education, allowing a transformation in the social and social context an economic improvement of this public.

Calegari et al. (2017) also points out that even promoting the transition of athletes from the Paralympics School Games, the high incidence of college athletes with disabilities competing for the first time can characterize this competition as revealing of Paralympic talents.

Thus, the maintenance of projects such as the Paralympics School and University Paralympics Games, combined with new Paralympic Sports Training Programs, demonstrate the commitment and the expansion of investments in the discovery of new Paralympic generations in Brazil.

In 2018, two important actions emerged to consolidate the process of sports initiation in the country: The School Camping and Paralympic Training Center. The Paralympic School Camping is a project that aims to insert athletes from 12 to 17 years old who stand out in the Paralympics School Games for an intensive training period at the Brazilian Paralympic Training Center.

The goal is to promote these young people to experience the routine of high-performance athletes, through training together with more experienced athletes of the Brazilian Paralympic movement, as well as passing tests and evaluations, specialized training and lectures with coaches of the main Brazilian teams.

In 2018, two Paralympic sports (swimming and athletics) were held. Already in 2019, it forms 11 modalities with about 98 young people contemplated (CPB, 2019b). Giving opportunity for students who participated in the Paralympic School Games to have a high-performance experience is a way to encourage these young athletes to stay in the sport.

To be a high-performance Paralympic athlete today is to have social and financial recognition, as in addition to the results, the federal, state and municipal governments' incentive for scholarships are extended to Paralympic sport (Pereira et al., 2019).

Also in 2018, the Sports Training Center was established in 2018 and aims, in addition to providing students with disabilities who are mostly exempted from physical education at school, to establish a Paralympic Sports Program at the Brazilian Paralympic Training Center for 500 adolescents aged 10 to 17 years, with physical, visual and intellectual disabilities, coming from the regular schools and specialized institutions of São Paulo and the metropolitan region, in eight Paralympic modalities: athletics, swimming, sitting volleyball, Paralympic boccia, 5-a-side football, goalball, judo and table tennis.

The discovery of new talent through the Sport Training Center - Paralympic Sports was innovative at CPB, as it works with an age group of young people with specialized accompaniment, selecting the best athletes during sports sessions for exclusive classes, designated as "Improvement". To select the students served in the "Improvement", the teachers analyse the students' sports practices and after a meeting, to study the cases, the student is invited to participate in this phase of the Project (Pereira et al., 2019).

In addition, the training of human resources to work in Paralympic sport has been strengthened and innovative in the country. Since 2006, with the emergence of the Paralympic of the future program (precursor 
within the Brazilian Paralympic movement), human resources training and capacity building has been implemented in the country.

In Brazil some initiatives are emerging to increase the number of human resources trained to work in Paralympic sport. CPB often offers technical qualification courses at different levels and different sports, workshops, workshops to prepare physical educators, physiotherapists, doctors, nutritionists, psychologists, massage therapists, nursing technicians and occupational therapists, among other professionals for Paralympic sport. In addition to theoretical participation, these professionals accompany and act in stages of Paralympic competitions for adults and young people in Brazil(Cardoso et al., 2018).

Recently the CPB launched the course "Paralympic Movement: Basic Fundamentals of Sport", in the Distance Learning Format (EaD), free of charge. The initiative is part of the goal of training up to 100,000 Physical Education professionals in adapted sports by 2025, defined in its Strategic Planning (CPB, 2019c).

Also, the importance of creation Brazilian Paralympic Training Center. This is the main legacy that the Rio 2016 Paralympic Games left for the Brazilian Paralympic sport. The complex is geared towards training, competitions and exchanges of athletes and teams dedicated to the development of Paralympic sport; physical preparation and training of new generations of athletes and training of coaches, functional classifiers, referees, managers and other professionals related to the sport. In addition, it should house a research centre in several scientific and technological areas associated with sport for people with disabilities (Cardoso et al., 2018).

The project received investments of $\mathrm{R} \$ 305$ million Brazilian reals, of which $\mathrm{R} \$ 187$ million from the federal government and R\$ 118 million from the state government of São Paulo (R\$ 281 million (works) and R\$ 24 million (sports equipment and materials) (BRASIL, 2016).

At the Rio de Janeiro Paralympic Games in 2016, it was not possible to see the influence of this structure on the results of Brazilian athletes, but for the 2020 Games in Tokyo, 2024 in Paris and 2028 in Los Angeles, future Brazilian Paralympic generations will be able to improve their preparation at this high quality training centre and contribute to maintaining Brazil among the powers of the world Paralympic sport.

New training centres or projects of creation (not necessarily in the same proportion) in different regions of the country can assist the renewal process for the Paris 2024 and Los Angeles 2028 Paralympic Games, so it will be possible to detect sports talents in different Paralympic modalities in all regions of the country.

\section{CONCLUSION}

The process of formation of new generations of Paralympic athletes happens continuously in the country. It is possible to highlight the growing number of programs and projects aimed at initiating young people with disabilities in the Brazilian Paralympic sport. Allied to this, it is possible to highlight the expansion and diversification of actions in the training and qualification of professionals who will work in the Paralympic sport.

Also, better quality sports facilities can provide real sports development possibilities for new athletes. It is worth highlighting the need to expand these actions to all federal units in the country. Maintaining financial support for Paralympic athletes is essential for future athletes to be able to focus exclusively on training and competitions. 
Thus, the Paralympic Games of 2024 and 2028, bring good perspectives for the Brazilian Paralympic sport, besides the possibility of proving the capacity of renewal of Paralympic talents, can consolidate the continuity of the country as power in the world Paralympic scenario.

\section{REFERENCES}

Bataglion, G., Mazo, J. (2019) Paralimpíadas Escolares (2006-2018): Evidências em mídias digitais acerca do evento esportivo. Recorde: Revista de História do Esporte, 12(1), 1 - 42.

Brasil (2014) Rede Nacional de Esporte - Edição 2014 das Paralimpíadas Escolares começa na terçafeira. Retrieved April 20, 2019, from: http://www.brasil.gov.br/noticias/esporte/2014/11/edicao-2014das-paralimpiadas-escolares-comeca-na-terca-25

Brasil (2015) Lei № 13.146, de 6 de julho de 2015. Institui a Lei Brasileira de Inclusão da Pessoa com Deficiência (Estatuto da Pessoa com Deficiência). Retrieved January 20, 2019, from: http://www.planalto.gov.br/ccivil_03/_Ato2015-2018/2015/Lei/L13146.html

Brasil (2016) Rede Nacional de Esporte - Centro de Treinamento Paralímpico inicia suas operações. 2016. Retrieved June 25, 2019, from:http://www.rededoesporte.gov.br//pt-br/noticias/centro-detreinamento-paralimpico-inicia-suas-operacoes

Calegari, D. C.; Senatore, V.; Nogueira, C. D.; Campeão, M.; Gorla, J. I.; Vieira, I. B. (2017) Profile of the athletes participation on the first brazilian paralympic games for university students. VISTA 2017 Scientific Conference, (1), 141-141.

Cardoso, V. D. (2016) O desenvolvimento da carreira esportiva de atletas paraolímpicos no Brasil. Doctoralthesis. Universidade Federal do Rio Grande do Sul. Retrieved October 06, 2019, from: https://www.lume.ufrgs.br/handle/10183/149557

Cardoso, V. D., Haiachi, M. C., ReppoldFilho, A. R., \& Gaya, A. C. A (2018). The structural and human resources support for Brazilian Paralympic athletes. Journal of Human Sport and Exercise, 13(1), 111. https://doi.org/10.14198/ihse.2018.134.14

Costa, A. M.; Santos, S. S. (2002) Participação do Brasil nos jogos paraolímpicos de Sydney: apresentação e análise. Revista Brasileira de Medicina do Esporte,8(3), 370-376. https://doi.org/10.1590/s1517-86922002000300002

CPB - Comitê Paralímpico Brasileiro (2015) Comitê Paralímpico Brasileiro celebra sanção da Lei de Inclusão da Pessoa com Deficiência. Retrieved June 25, 2019, from: http://cpb.org.br.187.38-89161.groveurl.com/comite-paralimpico-brasileiro-celebra- sancao-da-lei-de-inclusao-da-pessoacom-deficiencial

CPB-Comitê Paralímpico Brasileiro (2010). Planejamento estratégico do esporte paraolímpico brasileiro 2010-2016. Retrieved December 30, 2016, from http://www.cpb.org.br/wpcontent/uploads/Planejamento-Estrategico-2010-2016.pdf

CPB-Comitê Paralímpico Brasileiro (2019a) Paralímpiadas Escolares. Retrieved September 17, 2019 , from: http://www.cpb.org.br/competicoes/3

CPB-Comitê Paralímpico Brasileiro (2019b) Atletas e técnicos exaltam rotina no encerramento do Camping Escolar 2019. Retrieved September 17, 2019, from: http://www.cpb.org.br/noticia/detalhe/2396/atletas-e-tecnicos-exaltam-rotina-no-encerramento-docamping-escolar-2019

Gaya, A. (2008). Ciências do movimento humano Introdução à metodologia da pesquisa. Porto Alegre: Artmed.

Haiachi, M., C.; Cardoso, V. D.; Reppold Filho, A., \&Gaya, A. (2016). Reflexões sobre a carreira do atleta paraolímpico brasileiro. Ciência e Saúde Coletiva, 21(10), 2999-3006. https://doi.org/10.1590/1413812320152110.18512016 
Pereira, R.; Cabral, S.I.C.; Barboza, F.; Pereira, E.M.L.; Souza, S.; Pereira, L. Coordenação de esporte escolar do Comitê Paralímpico Brasileiro: projetos de massificação do Esporte paralímpico nacional. In: Oliveira, A.F.S.; Haiachi, M.C. (Org.). O Futuro dos Jogos Olímpicos e Paralímpicos. 2019, no prelo.

Reis, R. (2014) Políticas públicas para o esporte paralímpico brasileiro. Master dissertation. Universidade Federal do Paraná. Retrieved October 19, 2019, from: https://acervodigital.ufpr.br/handle/1884/36290

Silva, E. A. G. (2017) Projeto Paralímpiadas Escolares: intenção, evolução, articulações e contribuições ao paradesporto educacional brasileiro. Master dissertation. Universidade Federal do Paraná. Retrieved October 19, 2019, from: https://acervodigital.ufpr.br/handle/1884/47150 